\title{
A Review on Polyamines and Biotic Stresses in Plants
}

\author{
Md. Azizul Islam*, Pulak Maitra ${ }^{2}$, Dipa Mandal ${ }^{2}$ \\ ${ }^{1}$ Department of Biotechnology and Genetic Engineering, Faculty of Applied Science and Technology, Islamic University, \\ Kushtia-7003, Bangladesh \\ ${ }^{2}$ Colleges of Life Sciences, University of Chinese Academy of Sciences \\ Beijing 100049, China \\ Corresponding author's email: azizbge.iu [AT] gmail.com
}

\begin{abstract}
The biotic stresses are one of the main causes to the loss of crops, and their development, growth and productivity in the environment. Polyamines are positively charge compounds that have active potential power to DNA, RNA and protein (negative charge compounds), are exist in all living life for their low molecular weight and smallness. Naturally occurring polyamines are involved biotic stress response especially different plants disease and contribute the survival of plant in environment. They contribute a lot of different biological functions, such as controlling the cell cycle, protecting the cell, involve in gene expression, cell signaling replication, transcription, translation and membrane stabilization. This article specially highlights the recent advancement of polyamines in modern plant science research their impact of biotic stress specially the diseases caused by different microorganisms (bacteria, fungus) and creature systems.
\end{abstract}

Keywords - Plants, polyamines, biotic stresses, PR proteins, MAPKs.

\section{INTRODUCTION}

Polyamines are low molecular weight aliphatic cations that are ubiquitous present in all life organisms. Their first invention was made as early 1678, when crystals forms from human semen were first described [60] where, two polyamines (Spd and Spm) among three are responsible for the odor of semen. Naturally occurring two polyamines, Put (butane-1, 4-diamine) and cadaverine (pentane-1, 5-diamine), are formed by the decomposition of bacteria which are volatile materials [7]. In plants, there are present three types of major polyamines are putrescine, spermidine, and spermine. But another type of polyamine, cadaverine is present in legumes plant. Polyamines in plants have been mentioned to play important roles in growth, leaf senescence, embryogenesis, organ development, and abiotic and biotic stress response [26, 61, 30, 6, 29, 1, 8, and 27]. Polyamines are positive charge molecules; these compounds have high strong binding affinity to different cellular compounds, including DNA, RNA, chromatin and proteins. Thus, they have been maintain a lot of cellular processes, including regulation of gene expression, replication, transcription, translation, cell proliferation, modulation of cell signaling, and membrane stabilization [50, 8, and 21]. Polyamines can responsible for the regulation of cell death [54, 49]. Polyamines in plants are also contributing for agro-economical importance, including phytonutrient content, fruit quality, and vine life [35, 34 and 62]. Polyamines have defense response against the pathogen attack and reduce diseases [5]. Polyamines metabolism in plant cells create a suitable environment for the interacting the pathogens, such as fungal [4, 16], viral pathogens [55] and mycorrhizae [62]. Thus, a lot of experiments have been acquired regarding on polyamines and diseases of plant. For example, spermine (Spm) not only plays a role as a mediator in defense signaling against pathogen [51] but is also important for resistance to virus infection [65]. In this review, we summarize plant polyamines metabolism and their functions, with specific feature on biotic responses.

\section{BIOSYNTHESIS AND METABOLISM OF POLYAMINES IN PLANT}

The biosynthesis and metabolism of PAs in plants have been showed in figure 1. At the beginning step in the biosynthesis of polyamines that are catalyzed arginine- ornithine decarboxylases (ADC, ODC) from decarboxylation of arginine or ornithine to putrescine. Putrescine is synthesized from ADC pathway that is catalyzed three enzymes including ADC, N-carbamoylputrescine amidohydrolase (CPA) and agmatine iminohydrolase (AIH). Putrescine is synthesized from arginine by three enzymatic steps that are catalyzed by ADC, AIM and CPA. Higher molecular weight polyamine spermine is synthesized from spermidine that is catalyzed by SPM synthase and spermidine is synthesized by the enzyme SPM synthase from putrescine. The enzyme SAM decarboxylase catalyzes S-adenosylmethionine and produce aminopropyl groups. SAM is the main points for the production ethylene. Thus, encoding the genes sequences for all enzymatic activities, only ODC is exceptional in Arabidopsis plant. This plant has no ODC activity [19] and 
putrescine is produced from arginine pathway [24, 42]. There are also two genes responsible for SPD synthase (SPDS1 and SPDS2), two for SPM synthase (SPMS and ACL5) [20, 41] and four genes responsible for SAM decarboxylase (SAMDC1, 2, 3 and 4) [59].The enzyme diamine oxidases (DAOs) is responsible for the catalyze Put is converted into $\Delta^{1}$-pyrroline and as a byproducts are produces ammonia and $\mathrm{H}_{2} \mathrm{O}_{2}$. Diamine oxidases (DAO) are found in cell walls of plant, and hydrogen peroxide is produced by the catabolism of Put under salinity conditions. Put is converted in $\Delta^{1}$ pyrroline, is converted $\gamma$-aminobutyric acid (GABA), which is converted into succinic acid is a oxidative reactions that is occurred in Krebs cycle [14]. Polyamines have two important functions in plants, the first is ROS scavengers and the second is regulator of redox homeostasis [23]. The production of $\mathrm{H}_{2} \mathrm{O}_{2}$ in apoplasts or per-oxisomes due to the result of polyamines catabolism and anabolism by the enzymes of DAO and PAO [43]. $\mathrm{H}_{2} \mathrm{O}_{2}$ is a signal molecule and maintains a lot of processes, such as ion channel, salinity response process [40]. $\mathrm{H}_{2} \mathrm{O}_{2}$ maintains the signal in transcription levels [3] and role the adaptation of plant under unfavorable environments through the mediator of polyamines.

\section{PLANT-PATHOGEN INTERACTION}

Polyamines have a defense mechanism against biotic stress specially pathogens [64]. Hypersensitive response is one of the powerful defense mechanism against tobacco mosaic virus when entry into the cells of Nicotiana tabacum carrying the resistance gene and activates the cell death [55, 31]. It was noted that spermine located in the apoplast which express pathogen related protein-genes [65]. Spermine enhanced mitogen activated protein kinases or expressed hypersensitive genes when exogenously applied spermine to tobacco leaves and defense response against TMV and cell death [51, 57 and 37]. It is reported that mitochondria is inactivated when produce ROS (reactive oxygen species) in the cells are prerequisite [51] (Fig. 2). Mitochondria involves against pathogen (biotic stress) and PCD (programmed cell death) [2, 27]. Plant polyamines catabolism is linked with cells development, growth and function [9]. Yoda et al. [69, 68] reported that TMV infection to the tobacco leaves and cell death due to the catabolism of polyamines and produce $\mathrm{H}_{2} \mathrm{O}_{2}$. Thus, it is clear that plants polyamine catabolized to $\mathrm{H}_{2} \mathrm{O}_{2}$ and $\mathrm{H}_{2} \mathrm{O}_{2}$ is a defensive tool against biotic stresses [9, 63]. The overexpression of ZFT1 gene in tobacco plant prevent against tobacco mosaic virus [57, 58]. Overexpression of CaPFI gene in pine plants are more salinity and drought tolerance [52, 47]. It was noted that CaPF1 transgenic pine linked with polyamines biosynthesis and increased biotic tolerance [53].

Tun et al. [56] suggested that Spm (spermine) and Spd (spermidine) produce nitric oxide (NO) in Arabidopsis, but putrescine and arginine are not $[11,10]$. NO is a most important inhibitor to inhibits plant mitochondrial oxidative phosphorylation [67] and has a significant role in plant pathogen interactions [46, 45]; thus, it is needed more research for the production of NO through the mediator of polyamines are justified [66].

\section{PLANT-MYCORRHIZA INTERACTION}

Plants root development, their functions or the interaction between biotic components in soil (microorganisms) and the root tissues. Kytoviita and Sarjala [28] indicated that the symbiosis of mycorrhizae result to increased putrescine in scot pine roots. It is reported that exogenous applied Put in arbuscular mycorrhizae that results to increase the colony in the roots of pea [12, 13]. The function of PAs in arbuscular mycorrhizal infection was, therefore, postulated. Thus, it has been shown that the relationships between symbiotic and non-symbiotic roots have different polyamines level and reported that PA could create a suitable carbon sink environment for symbionts, as a result to fascination of photoassimilates [40]. Later, it was detected high amount of free PAs in mycorrhiza and Lotus glaber plants that compared with non-mycorrhiza plants $[17,48]$. The association induced resists host defense mechanism. It was also increased PAs level in plants and mycorrhiza. Moreover, the interactions between plants and mycorrhizae, and the role of PAs in symbiotic relationships are less studied [28].

\section{PLANT VIRUS INTERACTION}

Polyamines metabolism changes in HR of Nicotiana tabacum during the infection of tobacco mosaic virus (TMV). Negrel et al. [39] indicated that ornithine decarboxylase (ODC) was increased in Nicotiana tabacum leaves during the infection of TMV and accumulated high amounts of HCAAs (hydroxycinnamic acid amides), such as feruloylputrescine and feruloyltyramine [32, 22]. Study of tobacco cv Samsun NN showed that polyamines level changes in tobacco plants by the infection of tobacco mosaic virus and it was showed that high concentrations of putrescine and spermidine accumulated in the necrotic area of leaves and lesion formation [55, 25]. It was suggested that high amounts of polyamines are needed for the evolvement of necrotic lesion of leaves. Reduce $90 \%$ lesion formation in tobacco leaf discs by inoculation of TMV. This is indicated that HCAAs have active role in TMV resistance. Thus, PAs and HCAAs play an important role in hypersensitive response to TMV that protect viral replication [33]. 


\section{DEFENSE OF PLANT}

The external and internal environments of plants and their balance are equally maintained by plant organelles. It was reported that exogenously applied Spm (spermine) in Nicotiana tabacum leaves that leads to malfunction of mitochondria, increased marker gene (HR, hypersensitive response), mitogen activated protein kinases (MAPKs) and programmed cell death (PCD) [57, 37 and 36] and pathogen related proteins (PRPs) are induced by lesion formation in tobacco leaves when high amount of Spm are accumulated in cells and resistance against tobacco mosaic virus. Finally, it was identified that Spm activates two protein kinases including salicylic acid induced protein kinase and wound induced protein kinase and the expression of genes which involved to defense mechanism and they protect the plant $[15,51]$.

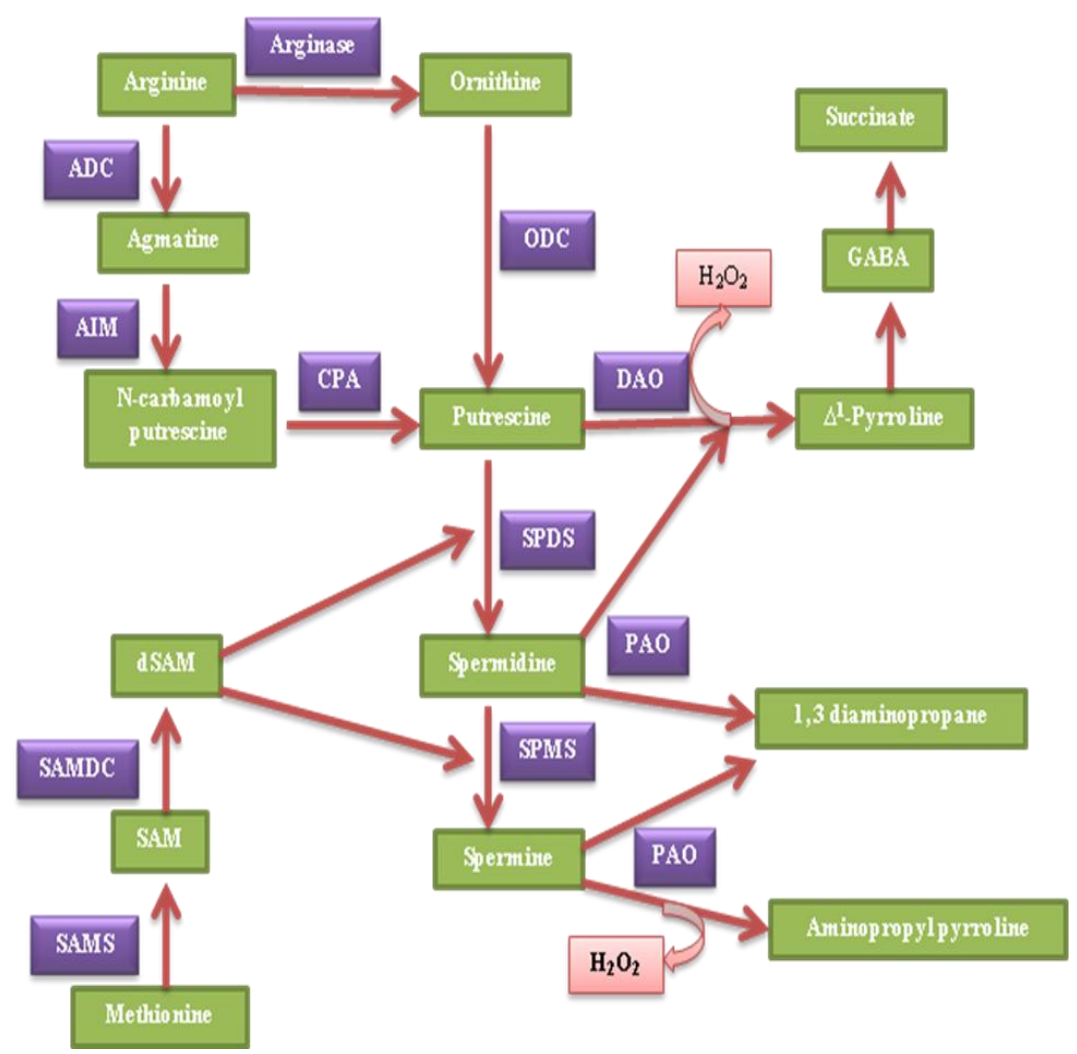

Figure 1: Common channel for the metabolism and synthesis of PAs in plant. ADC: Arginine decarboxylase, ODC: Ornithine decarboxylase, SPDS: Spermidine synthase, SPMS: Spermine synthase, AIM: Agmatine iminohydrolase, CPA: N-Carbamoyl putrescine amidohydrolase, DAO: Diamine oxidase, PAO: Polyamine oxidase, SAMDC: S-adenosylmethionine decarboxylase, SAM: S-adenosyl methionine,

GABA: $\gamma$-aminobutyric acid. 


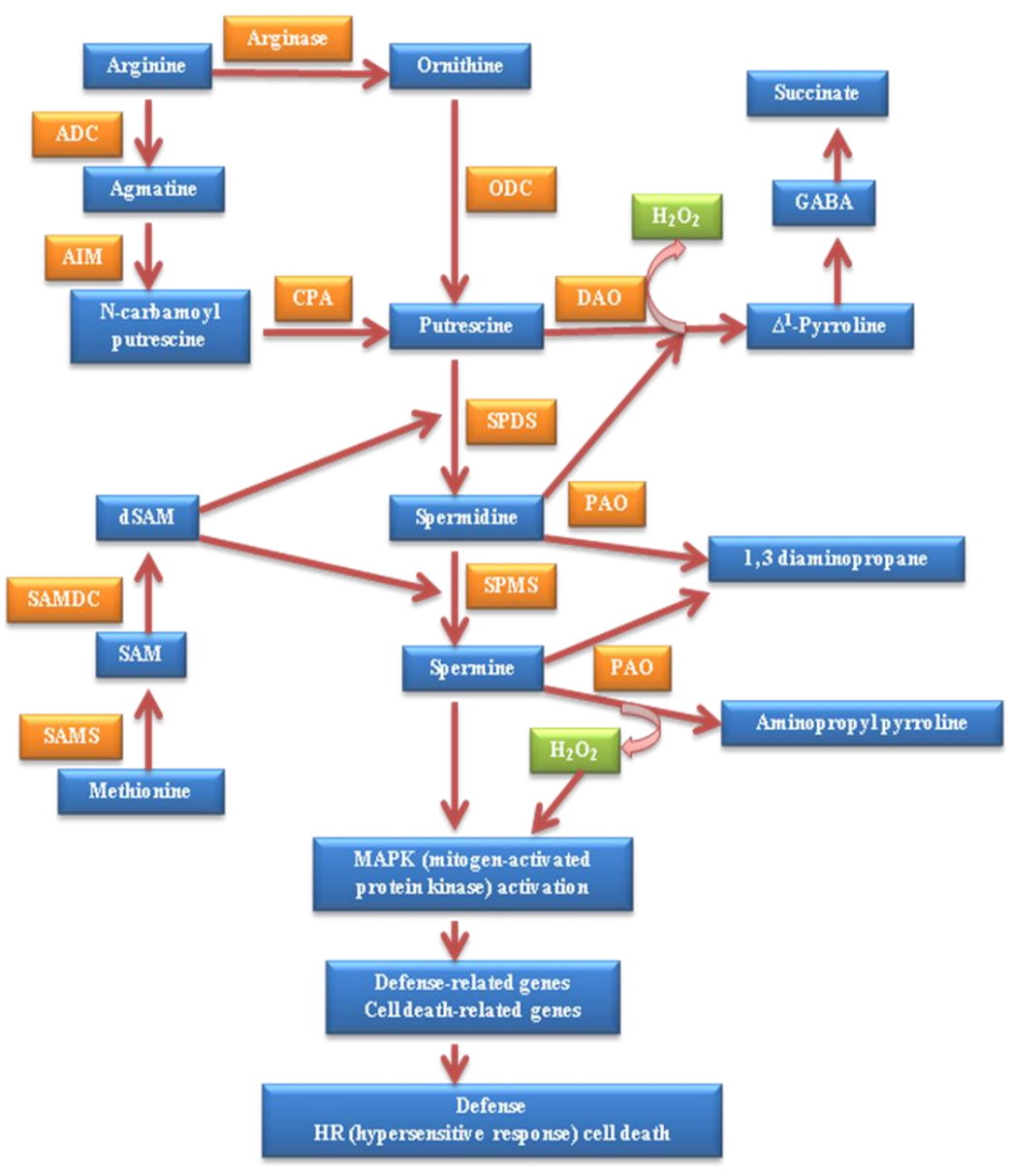

Figure 2: The hypothetical role of PAs in plant survival against pathogens.

\section{CONCLUSIONS AND FUTURE PROSPECTS}

Different food/vegetable crops in the worlds that are differently affected by biotic stresses and their productivity is decreasing every year. Thus, it is very necessary to improvement diseases resistant plant variety. Polyamines have physiological and cellular functions in biotic stress tolerance. To perceive the function of polyamines in growth and differentiation, the version of plant 'PAs modulation' has been elucidated. To find out the defense mechanisms or ion channels of polyamines that plays a defensive role in biotic stresses. Therefore, a lot of recent biological techniques required specially molecular biology and genetic engineering techniques (microarray, transcriptomics, metabolomics, proteomics, reverse genetics approaches) for the improvement of PAs transgenic plant to diseases resistant and their functions will be implicate in plant sciences.

\section{ACKNOWLEDGEMENT}

The authors like to thanks Islamic University-Kushtia, Bangladesh for their informative support. The authors did not receive any funding for this review.

\section{REFERENCES}

[1] Alcázar, R., Marco, F., Cuevas, J.C., Patron, M., Ferrando, A., Carrasco, P., Tiburcio, A.F., Altabella, T., "Involvement of polyamines in plant response to abiotic stress", Biotechnol Lett. vol. 28, pp. 1867-1876, 2006.

[2] Amirsadeghi, S., Robson, C.A., Vanlerberghe, G.C., "The role of the mitochondrion in plant responses to biotic stress", Physiol Plant. vol. 129, pp. 253-266, 2007.

[3] Andronis, E.A., Moschou, P.N., Toumi, I., Roubelakis-Angelakis, K.A., "Peroxisomal polyamine oxidase and NADPH-oxidase cross-talk for ROS homeostasis which affects respiration rate in Arabidopsis thaliana", Front. Plant Sci. vol. 5, PP. 132, 2014. 
[4] Asthir, B., Spoor. W., Duffus, C.M., "Involvement of polyamines, diamine oxidase and polyamine oxidase in resistance of barley to Blumeria graminis f. sp. Hordei”, Euphytica. vol. 136, pp. 307-12, 2004.

[5] Baileya, A., Strema, D., Baea, H., Myolob, G., Guiltinan, J., "Gene expression in leaves of Theobroma cacao in response to mechanical wounding, ethylene, and/or methyl jasmonate”, Plant Sci. vol. 168, pp. 1247-58, 2005.

[6] Bouchereau, A., Aziz, A., Larher, F., Martin-Tanguy, J., "Polyamines and environmental challenges: recent development", Plant Sci. vol. 140, pp. 103-125, 1999.

[7] Brieger, L., "Ueber Spaltungsprodukte der Bacterien, Zweite Mittheilung”, Zeitschr Physiol Chem. vol. 9, pp. 1-7, 1885.

[8] Cohen, S.S., “A guide to the polyamines”, Oxford University Press, New York. 1998.

[9] Cona, A., Rea, G., Angelini, R., Federico, R., Tavladoraki, P., "Functions of amine oxidases in plant development and defence", Trends Plant Sci. vol. 11, pp. 80-88, 2006.

[10] Del Duca, S., Betti, L., Trebbi, G., SeraWni-Fracassini, D., Torrigiani, P., "Transglutaminase activity changes during the hypersensitive reaction, a typical defense response of tobacco NN plants to TMV", Physiol Plant. vol. 131, pp. 241250, 2007.

[11] Della Mea, M., Caparro`s-Ruiz, D., Claparols, I., SeraWni-Fracassini, D., Rigau, J., “The first plant transglutaminase", Plant Physiol. Vol. 135, pp. 2046-2054, 2004.

[12] El-Ghachtouli, N., Paynot, M., Matin-Tanguy, J., Dorandi, D., Gianinazzi, S., "The effect of polyamines on endomycorrhizal infection of wild-type Pisumsativum, cv Frisson (nod+myc+) and two mutants (nod+myc- and nodmyc+)", Mycorrhiza. vol. 5, pp. 189-92, 1995.

[13] El-Ghachtouli, N., Paynot, M., Matin-Tanguy, J., Dorandi, D., Gianinazzi, S., "Effect of polyamines and polyamine biosynthesis inhibitors on spore germination and hyphal growth of Glomus mosseae", Mycol Res. vol. 100, pp. 597-600, 1996.

[14] Eller, M.H., Warner, A.L., Knap, H.T., "Genomic organization and expression analyses of putrescine pathway genes in soybean", Plant Physiol Biochem. vol. 44, pp. 49-57, 2006.

[15] Folk, J.E., Park. M.H., Chung, S.I., Schrode, J., Lester, E.P., Cooper, H.L., "Polyamines as physiological substrates for transglutaminases", J Biol Chem. Vol. 255, pp. 3695-3700, 1980.

[16] Greenland, A.J., Lewis, D.H., "Amines in barley leaves infected with brown rust and their possible relevance to formation of green islands”, New Phytol. vol. 96, pp. 283-91, 1984.

[17] Griffin, M., Casadio, R., Bergamini, C.M., "Transglutaminases: nature’s biological glues”, Biochem J. vol. 368, pp. 377-396, 2002.

[18] Groppa, M.D., Benavides, M.P., "Polyamines and abiotic stress: recent advances", Amino Acids. vol. 34, pp. 35-45, 2007.

[19] Hanfrey, C., Sommer, S., Mayer, M.J., Burtin, D., Michael, A.J., "Arabidopsis polyamine biosynthesis: absence of ornithine decarboxylase and the mechanism of arginine decarboxylase activity”, Plant J. vol. 27, pp. 551-560, 2001.

[20] Hanzawa, Y., Takahashi, T., Michael, A.J., Burtin, D., Long, D., Pineiro, M., Coupland, G, Komeda, Y., “ACAULIS5, an Arabidopsis gene required for stem elongation, encodes a spermine synthase” EMBO J. vol. 19, pp. 4248-4256, 2000.

[21] Igarashi, K., Kashiwagi, K., "Polyamines: mysterious modulators of cellular functions", Biochem Biophys Res Commun. vol. 271, pp. 559-564, 2000.

[22] Iwata, Y., Koizumi, N., "An Arabidopsis transcription factor, Atb-ZIP60, regulates the endoplasmic reticulum stress response in a manner unique to plants", Proc Natl Acad Sci USA. vol. 102, pp. 5280-5285, 2005.

[23] Saha, J., "Polyamines as redox homeostasis regulators during salt stress in plants", Front Environ Sci. vol. 3, pp. 21, 2015.

[24] Janowitz, T., Kneifel, H., Piotrowski, M., "Identification and characterization of plant agmatine iminohydrolase, the last missing link in polyamine biosynthesis of plants", FEBS Lett. vol. 544, pp. 258-261, 2003.

[25] Kamauchi, S., Nakatani, H., Nakano, C., Urade, R., "Gene expression in response to endoplasmic reticulum stress in Arabidopsis thaliana”, FEBS J. vol. 272, pp. 3461-3476, 2005.

[26] Kumar, A., Altabella, T., Taylor, M., Tiburcio, A.F., "Recent advances in polyamine research", Trends Plant Sci. vol. 2, pp. 124-130, 1997.

[27] Kusano, T., Yamaguchi, K., Berberich, T., Takahashi, Y., “The polyamine spermine rescues Arabidopsis from salinity and drought stresses", Plant Signal Behav. vol. 2, pp. 250-251, $2007 \mathrm{~b}$.

[28] Kytoviita, M.M., Sarjala, T., "Effects of defoliation and symbiosis on polyamine levels in pine and birch", Mycorrhiza. vol. 7, pp. 107-11, 1997.

[29] Liu, K., Fu, H., Bei, Q., Luan, S., "Inward potassium channel in guard cells as a target for polyamine regulation of stomatal movements", Plant Physiol. vol. 124, pp. 1315-1326, 2000.

[30] Malmberg, R.L., Watson, M.B., Galloway, G.L., Yu, W., "Molecular genetics analyses of plant polyamines", Crit Rev Plant Sci. vol. 17, pp. 199-224, 1998.

[31] Marini, F., Betti, L., Scaramagli, S., Biodi, S., Torrigiani, P., "Polyamine metabolism is upregulated in response to tobacco mosaic virus in hypersensitive, but not in susceptible, tobacco", New Phytol. vol. 149, pp. 301-309, 2001. 
[32] Martin-Tanguy, J., Martin, C., Gallet, M., "Presence de composes aromatiques lies a la putrescine dans divers Nicotiana viruses", Comptes Rendus des Seances de l'Academie des Sciences, Paris D276, pp. 1433-1435, 1973. (in French).

[33] Martin-Tanguy, J., Martin, C., Gallet, M., Vernoy, R., "Sur le puissants inhibitors de multiplication du virus de la mosaique de tabae", Comptes Rendus des Seances de l'Academie des Sciences, Paris D282, pp. 2231-2234, 1976. (in French).

[34] Matto, A.K., Sobolev, A.P., Neelam, A., Goyal, R.K., Handa, A.K., Segre, A.L., "Nuclear magnetic resonance spectroscopy-based metabolite profiling of transgenic tomato fruit engineered to accumulate spermidine and spermine reveals enhanced anabolic and nitrogen- carbon interactions", Plant Physiol. vol. 142, pp. 1759-1770, 2006.

[35] Mehta, R.A., Cassol, T., Li, N., Ali, N., Handa, A.K., Matto, A.K., "Engineered polyamine accumulation in tomato enhances phytonutrient content, juice quality, and vine life", Nat Biotechnol. vol. 20, pp. 613-618, 2002.

[36] Mitsuya, Y., Takahashi, Y., Berberich, T., Miyazaki, A., Matsumura, H., Takahashi, H., Terauchi, R., Kusano, T., "Spermine signaling plays a significant role in the defense response of Arabidopsis thaliana to cucumber mosaic virus", J Plant Physiol. vol. 166, pp. 626-43, 2009.

[37] Mitsuya, Y., Takahashi, Y., Uehara, Y., Berberich, T., Miyazaki, A., Takahashi, H., Kusano, T., "Identification of a novel Cys2/His2-type zinc Wnger protein as a component of a spermine-signaling pathway in tobacco", J Plant Physiol. vol. 164, pp. 785-793, 2007.

[38] Moschou, P.N., "Spermidine exodus and oxidation in the apoplast induced by abiotic stress is responsible for $\mathrm{H}_{2} \mathrm{O}_{2}$ signatures that direct tolerance responses in tobacco", Plant Cell. vol. 20, pp. 1708-1724, 2008.

[39] Negrel, J., Vallee, J.C., Martin, C., "Ornithine decarboxylase activity and the hypersensitive reaction of tobacco to tobacco mosaic virus in Nicotiana tabacum", Phytochemistry. vol. 23, pp. 2747- 2751, 1984.

[40] Niemi, K., Haggman, H., Sarjala, T., "Effects of exogenous diamines on the interaction between ectomycorrhizal fungi and adventitious root formation in Scots pine in vitro", Tree Physiol. Vol. 22, pp. 373-81, 2002.

[41] Panicot, M., Minguet, E.G., Ferrando, A., Alcázar, R., Blázquez, M.A., Carbonell, J., Altabella, T., Koncz, C., Tiburcio, A.F., "A polyamine metabolon involving aminopropyl transferases complexes in Arabidopsis", Plant Cell. vol. 14, pp. 2539-2551, 2002.

[42] Piotrowski, M., Janowitz, T., Kneifel, H., "Plant C-N hydrolases and the identification of a plant Ncarbamoylputrescine amidohydrolase involved in polyamine biosynthesis”, J Biol Chem. vol. 278, pp. 1708-1712, 2003.

[43] Pottosin, I., Shabala, S., "Polyamines control of cation transport across plant membranes: implications for ion homeostasis and abiotic stress signaling, Front", Plant Sci. vol. 5, pp. 154, 2014.

[44] Poulin, R., Pelletier, G., Pegg, A.E., "Induction ofapoptosis by excessive polyamine accumulation in ornithine decarboxylase overproducing L1210 cells". Biochemical Journal. vol. 311, pp. 723-727, 1995.

[45] Rhee, H.J., Kim, E.J., Lee, J.K., "Physiological polyamines: simple primordial stress molecules", J Cell Mol Med. vol. 11, pp. 685-703, 2007.

[46] Romero-Puertas, M.C., Perazzolli, M., Zago, E.D., Delledonne, M., "Nitric oxide signalling functions in plantpathogen interactions" Cell Microbiol. vol. 6, pp. 795-803, 2004.

[47] Rutkowski, D.T., Kaufman, R.J, “A trip to the ER: coping with stress”, Trends Cell Biol. vol. 14, pp. $20-28,2004$.

[48] Sannazzaro, A.I., Echeverria, M., Alberto, E.O., Ruiz, O.A., Menendez, A.B., "Modulation of polyamine balance in Lotus glaber by salinity and arbuscular mycorrhiza", Plant Physiol Biochem. vol. 45, pp. 39-46, 2007.

[49] Seiler, N., Raul, F., "Polyamines and apoptosis", J Cell Mol Med. vol. 9, pp. 623-642, 2005.

[50] Tabor, CW., Tabor, H., "Polyamines", Annu Rev Biochem 53, pp. 749-790, 1984.

[51] Takahashi, Y., Berberich, T., Miyazaki, A., Seo, S., Ohashi, Y., Kusano, T., "Spermine signaling in tobacco: activation of mitogen-activated protein kinases by spermine is mediated through mitochondrial dysfunction", Plant J. vol. 36, pp. 820-829, 2003.

[52] Tang, W., Charles, T.M., Newton, R.J, “Overexpression of the pepper transcription factor CaPF1 in transgenic Virginia pine (Pinus virginiana Mill) confers multiple stress tolerance and enhances organ growth”, Plant Mol Biol. vol. 59, pp. 603-617, 2005.

[53] Tang, W., Newton, R.J., Li, C., Charles, T.M., "Enhanced stress tolerance in transgenic pine expressing the pepper CaPF1 gene is associated with the polyamine biosynthesis", Plant Cell Rep. vol. 26, pp. 115-124, 2007.

[54] Thomas, T., Thomas, T.J, "Polyamines in cell growth and cell death: molecular mechanisms and therapeutic applications", Cell Mol Life Sci. vol. 58, pp. 244-258, 2001.

[55] Torrigiani, P., Rabiti, A.L., Bortolotti, C., Betti, L., Marani, F., Canova, A., Bagni, N., "Polyamine synthesis and accumulation in the hypersensitive response to TMV in Nicotiana tabacum", New Phytol. vol. 135, pp. 467-473, 1997.

[56] Tun, N.N., Santa-Catarina, C., Begum, T., Silveira, V., Handro, W., Floh, E.I., Scherer, G.F, "Polyamines induce rapid biosynthesis of nitric oxide (NO) in Arabidopsis thaliana seedlings", Plant Cell Physiol. vol. 47, pp. 346-354, 2006.

[57] Uehara, Y., Takahashi, Y., Berberich, T., Miyazak, A., Takahashi, H., Matsui, K., Ohme-Takagi, M., Saitoh, H., Terauchi, R., Kusano, T., "Tobacco ZFT1, a transcriptional repressor with a Cys2/His2 typezinc Wnger motif that functions in spermine-signaling pathway", Plant Mol Biol. vol. 59, pp. 435-448, 2005. 
[58] Urade, R., "Cellular response to unfolded proteins in the endoplasmic reticulum of plants", FEBS J. vol. 274, pp. 1152-1171, 2007.

[59] Urano, K., Yoshiba, Y., Nanjo, T., Ito, T., Yamaguchi-Shinozaki, K., Shinozaki, P., “Arabidopsis stress-inducible gene for arginine decarboxylase AtADC2 is required for accumulation of putrescine in salt tolerance", Biochem Biophys Res Comm. vol. 313, pp. 369-375, 2004.

[60] Van Leeuwenhoek, A., "Observationes D. Anthonii Leeuwenhoek, de natis e semine genitali animalculis", Philos Trans R Soc Lond 12, pp. 1040-1043, 1678.

[61] Walden, R., Cordeiro, A., Tiburcio, A.F., "Polyamines: small molecules triggering pathways in growth and development", Plant Physiol. vol. 113, pp. 1009-1013, 1997.

[62] Walters, D.R., "Polyamines in plant-microbe interactions", Physiol Mol Plant Pathol. vol. 57, pp. 137-46, 2000.

[63] Walters, D.R., "Polyamines and plant diseases", Phytochemistry. vol. 64, pp. 97-107, 2003.

[64] Walters, D.R., "Resistance to plant pathogens: possible roles for free polyamines and polyamine catabolism", New Phytol. vol. 159, pp. 109-115, 2003a.

[65] Yamakawa, H., Kamada, H., Satoh, M., Ohashi, Y., "Spermine is a salicylate-independent endogenous inducer for both tobacco acidic pathogenesis-related proteins and resistance against tobacco mosaic virus infection", Plant Physiol. vol. 118, pp. 1213-22, 1998.

[66] Yamasaki, H., Cohen, M.F., "NO signal at the crossroads: polyamine-induced nitric oxide synthesis in plants", Trends Plant Sci. vol. 11, pp. 522-524, 2006.

[67] Yamasaki, H., Shimoji, H., Ohshiro, Y., Sakihama, Y., "Inhibitory effects of nitric oxide on oxidative phosphorylation in plant mitochondria”, Nitric Oxide. vol. 5, pp. 261-270, 2001.

[68] Yoda, H., Hiroi, Y., Sano, H., "Polyamine oxidase is one of the key elements for oxidative burst to induce programmed cell death in tobacco cultured cells", Plant Physiol. vol. 142, pp. 193-206, 2006.

[69] Yoda, H., Yamaguchi, Y., Sano, H., "Induction of hypersensitive response by hydrogen peroxide produced through polyamine degradation in tobacco plants", Plant Physiol. vol. 132, pp. 1973-1981, 2003. 